\title{
Distribution, variation, and relationship of Curcuma soloensis Valeton in Java, Indonesia based on morphological characters
}

\author{
MUHAMAD JALIL ${ }^{1, \vartheta}$, AZIZ PURWANTORO ${ }^{2, v \vee}$, BUDI SETIADI DARYONO ${ }^{3, v \vee v, ~ P U R N O M O ~}{ }^{4, v \vee v \vee}$ \\ ${ }^{1}$ Faculty of Biology, Universitas Gadjah Mada. Jl. Teknika Selatan, Sleman 55281, Yogyakarta, Indonesia. Tel.: +62-274-580839, Fax.: +62-274-6492355, \\ •email: emjie.jack@gmail.com \\ ${ }^{2}$ Department of Agronomy, Faculty of Agriculture, Universitas Gadjah Mada. Jl. Flora No. 1, Bulaksumur, Sleman 55281, Yogyakarta, Indonesia. \\ Tel.: +62-274-563062, “凶email: ronsasm@ @otmail.com \\ ${ }^{3}$ Laboratory of Genetics and Breeding, Faculty of Biology, Universitas Gadjah Mada. Jl. Teknika Selatan, Sleman 55281, Yogyakarta, Indonesia. \\ Tel.: +62-274-580839, Fax.: +62-274-6492355, •*vemail: bs_daryono@mail.ugm.ac.id \\ ${ }^{4}$ Laboratory of Plant Systematics, Faculty of Biology, Universitas Gadjah Mada. Jl. Teknika Selatan, Sleman 55281, Yogyakarta, Indonesia. \\ Tel.: +62-274-580839, Fax.: +62-274-6492355, "vv»email: purnomods@ugm.ac.id
}

Manuscript received: 18 June 2020. Revision accepted: 29 July 2020.

\begin{abstract}
Jalil M, Purwantoro A, Daryono BS, Purnomo. 2020. Distribution, variation, and relationship of Curcuma soloensis Valeton in Java, Indonesia based on morphological characters. Biodiversitas 21: 3867-3877. Curcuma soloensis Valeton (locally called temu genyeh) was a plant originating from Solomon Islands and was synonymous with Curcuma longa L. This plant was often considered to be turmeric (Curcuma longa Linn.) or temulawak (Curcuma zanthorrhiza Roxb.), because the rhizome is almost the same color. The purpose of this study was to determine the distribution, variation, and relationship of $C$. soloensis in Java, Indonesia. Retrieval of data with exploratory roaming methods in 12 districts/cities in Java Island as a center for planting medicinal plants. Morphological character observations were made on habit, rhizome, roots, tubers, leaves, pseudo-stems, and flowers. Morphological data were analyzed by descriptive and numerical methods. Analysis of grouping with Gower Coefficients because it uses 45 binary and multistate data. Principal Component Analysis (PCA) was performed to determine the role of each character in the grouping. Cluster analysis and PCA graphics were assisted with MVSP 3.1 software. The results of the study were obtained from 25 accessions of $C$. soloensis in East Java (Trenggalek, Pacitan, Ponorogo), Central Java (Wonogiri, Karanganyar, Magelang, Semarang), Yogyakarta (Yogyakarta City, Bantul, Gunungkidul), and West Java (Ciamis and Tasikmalaya). The variation of $C$. soloensis lies in habit, stem color, leaf shape, rhizome shape, rhizome flesh color, and tuber shape. The highest abundance percentage is in Pajangan, Tirtomoyo, and Tawangmangu. The dendrogram divides 32 OTUs into two clusters on the phenon line 0.617 , namely cluster A (C. zanthorrhiza) and cluster B (C. soloensis and $C$. longa). PCA results showed that the characters that had the most role in grouping were leaf blade color, leaf blade length, rhizome shape, root color, rhizome taste, outer and inner rhizome flesh color.
\end{abstract}

Keywords: Curcuma, cluster analysis, description, PCA, taxonomy, UPGMA

\section{INTRODUCTION}

Curcuma soloensis Valeton originally described from Java, Indonesia (locally called temu genyeh) (Heyne 1987; Valeton 1918) as separate species than Curcuma longa L. under Section Mesantha of Zingiberaceae (Valeton 1918). However, in the Flora of Java, Curcuma soloensis Valeton and $C$. longa $\mathrm{L}$. are included as the members of the collective species Curcuma viridiflora Roxb. (Backer and van den Brink 1968). At present, Kew Science (2020) and Theplantlist (2020) considers C. soloensis Valeton to be synonymous to $C$. longa $\mathrm{L}$. As South Asia and Southeast Asia belt is home to rich diversity of Zingiberaceae,e morphological and molecular studies are necessary to further enhance our knowledge about the plant family, including members of the genus Curcuma. Such studies may help in discovering new subgeneric taxa of Curcuma and solving taxonomic uncertainties.

Curcuma soloensis is a native plant of Solomon Islands and is wildly cultivated in Southeast Asia (Zhang et al. 2011). This introduced plant in the Surakarta and surrounding areas (Marliyana et al. 2018) of Java Island,
Indonesia and has now been naturalized (Bos et al. 2007) and finds medicinal use through local Hortus Medicus clinic and the Tawangmawu Center for Traditional Medicinal Plants and Medicines (B2P2TOOT Tawangmangu) in Central Java, Indonesia. Though less popular than turmeric (Curcuma longa Linn. Syn. Curcuma domestica Valeton) in terms of utilization (Subositi and Wahyono 2019), population of C. soloensis in Java Island has diminished due to local medicinal extraction and is available mostly under cultivation only (Roemantyo 2000). Rhizomes of $C$. soloensis is rich source of terpenoids, sesquiterpenes, curcuminoids (Bos et al. 2007; Hayakawa et al. 2011; Anuchapreeda et al. 2018) which has antifungal, antioxidant, anti-inflammatory, anticancer activities (Kocaadam and Lieranlier 2017; Mishra et al. 2018; Diastuti et al. 2019). Besides, the presence of beautiful violet-red colored bractea makes $C$. soloensis a potential ornamental and it is cultivated through tissue culture for ornamental use in China (Zhang et al. 2011).

Due to phenotypic similarities between species (Apavatjrut et al. 1999) identity of members of Curcuma group and C. soloensis are often confused in Javanese 
society. As observed in Pasar Imogiri, Bantul, Yogyakarta, Indonesia rhizomes of $C$. soloensis were mixed with temulawak (C. zanthorrhiza Roxb.) and turmeric or kunir (C. longa Linn.) because of their identical rhizome color. Due to unclear boundaries between members of Curcuma, it has been recommended to realign species within genus Curcuma (Kress 2002), which in a way minimize misidentification of $C$. soloensis, allow conservation of $C$. soloensis and proper certification and registration of new cultivars. Building strong taxonomic evidence and their assessment through phenetic and phylogenetic approaches are known to clarify taxonomic boundaries (Backer and van den Brink 1968; Silva et al. 2018), which would be helpful in solving identification problems with $C$. soloensis.

In this study distribution of $C$. soloensis in Java was studied, along with variations and patterns between species of Curcuma through cluster analysis and principal component analysis based on phenetic characteristics of habit, rhizome, roots, tubers, leaves, pseudo-stems and flowers for compiling the interspecific classification of $C$. soloensis in Java, Indonesia.

\section{MATERIALS AND METHODS}

The study was conducted from January 2019 until June 2020. Identification of morphological characters was carried out in the field. Sampling of $C$. soloensis accessions was conducted in twelve (12) districts/cities in Java, Indonesia namely East Java (Trenggalek, Pacitan, Ponorogo), Central Java (Wonogiri, Karanganyar, Magelang, Semarang), Yogyakarta (Yogyakarta City, Bantul, Gunungkidul), and West Java (Ciamis and Tasikmalaya) (Figure 1).

Equipment used to obtain morphological data: descriptor books, GPS, crowbars, hoes, sewing meters, rulers, pencils, shovels, scissors, cutters, and digital cameras. Observed color was compared with the color codes of RHS (Royal Horticultural Society). Photographs of plant and plant parts were arranged in plates using Corel Draw X5. Morphological features like habit, rhizome, roots, tubers, leaves, pseudo-stems, and flowers of $C$. soloensis were compared. Comparison groups in this study are $C$. longa and $C$. zanthorrhiza.

Samples were identified by matching the morphological data with the description and image of the $C$. soloensis specimens (Backer and van den Brink 1968; Delin and Larsen 2000; Sasikumar 2005). Samples were observed for their morphological characters and scoring following the Sasikumar descriptors (Sasikumar 2005), using 45 qualitative and quantitative characters (Table 1), which is more than the characters used in earlier study of Sungkawati et al. (2019). Cluster analysis and PCA graphics were assisted with MVSP 3.1 software. Abundance was analyzed by descriptive percentage.

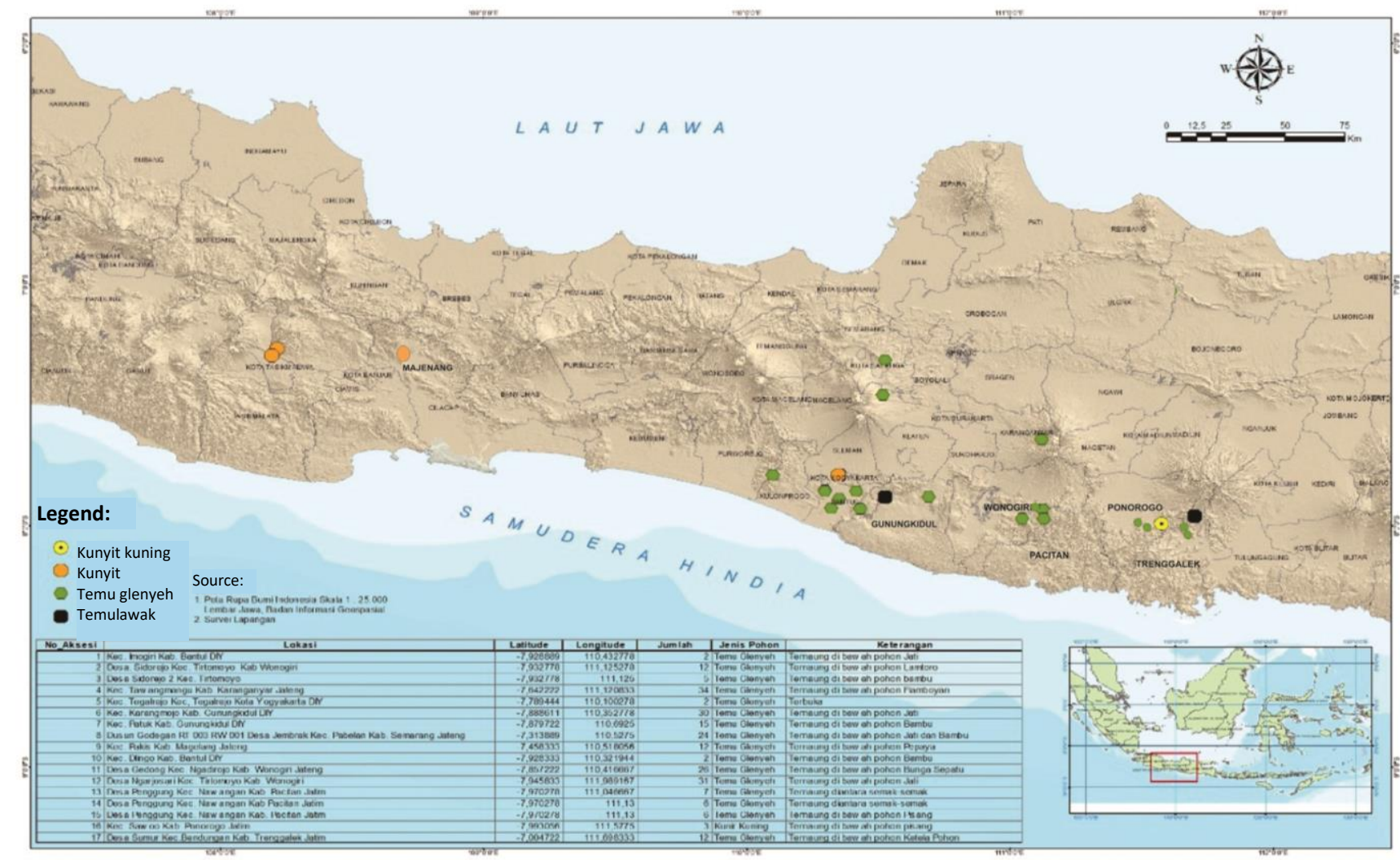

Figure1. Distribution and sampling locations of Curcuma soloensis in Java Island, Indonesia 
Table 1. Morphological characters of Curcuma soloensis observed (Sasikumar 2005)

\begin{tabular}{|c|c|}
\hline Character & Note \\
\hline Plant type & $0=$ erect ; semi erect $=1$ \\
\hline Plant height & $0=0-0,9 \mathrm{~m} ; 1=1-1,9 \mathrm{~m} ; 2=2-2,9 \mathrm{~m}$ \\
\hline \multirow[t]{2}{*}{ Habit of leaves } & $0=$ erect $; 1=$ semi erect $; 2=$ prostrate \\
\hline & $\begin{array}{l}0=\text { yellow green group } 151 \text {-strong greenish yellow a; } 1=\text { green group } 143 \text {-strong yellow } \\
\text { green b; } 2=\text { yellow green } 144 \text {-strong yellow green a; } 3=\text { yellow green group } 144 \text {-strong } \\
\text { yellow green b; } 4=\text { yellow green group } n 144 \text {-strong yellow b; } 5=\text { yellow green group } \\
\text { 146-moderate yellow green b; } 6=\text { yellow green group } 145 \text {-moderate yellow green b; } \\
\text { strong yellow green a }\end{array}$ \\
\hline Number of pseudo-stems & $0=1-5$ terna $; 1=6-10$ terna $; 2=11-15$ terna $3=\geq 15$ terna \\
\hline \multirow[t]{2}{*}{ Leaf stalk texture } & $0=$ glabrous $; 1=$ hairy \\
\hline & $\begin{array}{l}0=\text { green group } 137 \text {-moderate olive green } \mathrm{a} ; 1=\text { green group } 137 \text {-moderate olive green } \\
\mathrm{b} ; 2=\text { green group } 138 \text { - moderate yellowish green } \mathrm{a} ; 3=\text { green group } 143 \text {-strong yellow } \\
\text { green } \mathrm{a} ; 4=\text { green group } 143 \text {-strong yellow green } \mathrm{b} ; 5=\text { yellow green group } 144 \text {-strong }\end{array}$ \\
\hline Leaf blade color & yellow green a; $6=$ yellow green group 144 -strong yellow green b \\
\hline Leaf shape & $0=$ round $(1: 1) ; 1=$ ovate $(1.5-2: 1) ; 2$ oblong $(2.5-3: 1) ; 3=$ lancet $(3-5: 1)$ \\
\hline Leaf tip & $0=$ tapered (acuminate) $; 1=\operatorname{sharp}($ acute $)$ \\
\hline Leaf base & $0=$ attenuate $; 1=$ rounded $; 2=$ obtuse $; 3=$ sharp $($ acute $)$ \\
\hline Leaf length (vagina) & $0=1-50 \mathrm{~cm}=; 1=51-100 \mathrm{~cm}=; 2=101-150 \mathrm{~cm}$ \\
\hline Leaf length (lamina) & $0=15-40 \mathrm{~cm} ; 1=41-66 \mathrm{~cm} ; 2=67-92 \mathrm{~cm} ; 3=93-118 \mathrm{~cm}$ \\
\hline Leaf width & $0=5-13 \mathrm{~cm} ; 1=14-22 \mathrm{~cm} ; 2=23-31 \mathrm{~cm} ; 3=32-40 \mathrm{~cm}$ \\
\hline The number of leaves in a pseudo-stem & $0=1-5$ leaves; $1=6-10$ leaves \\
\hline Leaf margin & $0=$ low wavy $(1-7 \mathrm{~cm}) ; 1=$ medium wavy $(8-14 \mathrm{~cm}) ; 2=$ highly wavy $(15-22 \mathrm{~cm})$ \\
\hline Leaf vein & $0=\operatorname{close}(<1 \mathrm{~cm}) ; 1=\operatorname{distant}(>1 \mathrm{~cm})$ \\
\hline Dorsal surface of the leaf & $0=$ hairy $; 1=$ glabrous \\
\hline Ventral surface of the leaf & $0=$ hairy $; 1=$ glabrous \\
\hline Mid-rib leaf color & $0=$ green $; 1=$ purple \\
\hline Mid-rib tinge on dorsal surface & $0=$ present $; 1=$ absent \\
\hline Mid-rib tinge on ventral surface & $0=$ present $; 1=$ absent \\
\hline Early Growth & $0=$ generative $; 1=$ vegetative \\
\hline Inflorescence position & $0=$ lateral $; 1=$ terminal \\
\hline Rhizome shape & $0=$ ovate $; 1=$ cone $; 2=$ round $3=$ lengthwise $; 4=$ ellipse \\
\hline Nature of rhizome & $0=$ sessile tubers present $; 1=$ sessile tubers absent $; 2=$ stoloniferous \\
\hline Root shape & $0=$ oblong $; 1=$ cylindrical \\
\hline Root color & $0=$ yellow $; 1=$ chocolate $; 2=$ black $; 3=$ white \\
\hline Root length & $0=1-10 \mathrm{~cm} ; 1=11-20 \mathrm{~cm} ; 2=21-30 \mathrm{~cm} ; 3=31-40 \mathrm{~cm}$ \\
\hline Presence of tubers & $0=$ absent $1=$ present \\
\hline Presence of stolon & $0=$ absent $; 1=$ present \\
\hline Aroma of rhizome & $0=$ mango $; 1=$ camphoraceous $; 2=$ turmeric $; 3=$ non aromatic $; 4=$ harsh \\
\hline Taste & $0=$ bitter; $1=$ sweet $2=$ inert $3=$ turmeric flavor; $4=$ bitterly spicy \\
\hline The secondary rhizome & $0=$ present $; 1=$ absent \\
\hline \multirow[t]{2}{*}{ Endodermic ring in the primary rhizome } & $0=$ clear $; 1=$ unclear \\
\hline & $\begin{array}{l}0=\text { yellow-orange group-14-vivid yellow a; } 1=\text { greyed-orange group } 163 \text {-strong orange } \\
\text { yellow b; } 2=\text { yellow group } 12 \text {-vivid yellow a; } 3=\text { greyed-orange group } 163 \text {-deep orange } \\
\text { yellow a; } 4=\text { yellow group } 2 \text {-vivid greenish yellow a; } 5=\text { yellow group } 9 \text {-vivid yellow a; } \\
6=\text { orange group n } 25 \text {-strong orange } b\end{array}$ \\
\hline Color of outer rhizome flesh & $\begin{array}{l}0=\text { greyed-orange group } 163 \text {-deep orange yellow a; } 1=\text { greyed-orange group } 163 \text {-strong } \\
\text { orange yellow b; } 2=\text { greyed-orange group } 164 \text {-brownish orange a; } 3=\text { orange group } \\
\text { n25-stronge orange a; } 4=\text { greyed-orange group n167-brownish orange a; } 5=\text { orange }\end{array}$ \\
\hline Color of inner rhizome flesh & group $\mathrm{n} 25$-strong orange $\mathrm{b}$ \\
\hline Rhizome outer skin color & $0=$ orange $; 1=$ chocolate $; 2=$ orange-yellowish \\
\hline Number of branching rhizomes & $0=2-5$ pieces; $1=6-9$ pieces; $2=10-13$ pieces \\
\hline Number of rhizome segments & $0=3-6$ pieces; $1=7-10$ pieces; $2=11-14$ pieces \\
\hline Rhizome diameter & $0=1-3 \mathrm{~cm} ; 1=4-6 \mathrm{~cm} ; 2=7-9 \mathrm{~cm} ; 3=10-12 \mathrm{~cm}$ \\
\hline Perimeter the Rhizome & $0=1-10 \mathrm{~cm} ; 1=11-20 \mathrm{~cm} ; 2=21-30 \mathrm{~cm} ; 3=>30 \mathrm{~cm}$ \\
\hline Length of secondary rhizome (entik) & $0=1-6 \mathrm{~cm} ; 1=7-13 \mathrm{~cm} ; 2=14-19 \mathrm{~cm}$ \\
\hline Endodermic ring at entik & $0=$ clear $; 1=$ unclear \\
\hline Entik diameter & $0=1-3 \mathrm{~cm} ; 1=4-6 \mathrm{~cm}$ \\
\hline Perimeter of entik & $0=1-6 \mathrm{~cm} ; 1=7-12 \mathrm{~cm} ; 3=13-18 \mathrm{~cm}$ \\
\hline
\end{tabular}




\section{RESULTS AND DISCUSSION}

\section{Distribution of Curcuma soloensis Valeton in Java}

Based on the results of exploration explorations that have been carried out, obtained 25 samples (accessions) of C. soloensis and 7 comparison groups in 12 districts or cities in Java Island. Accessions of $C$. soloensis found in Java are shown in Table 2. Valeton (1918), divided Curcuma in Java and Sumatra into two sections namely Mesantha and Exantha. C. soloensis and C. longa enter Meshanta, while $C$. zanthorrhiza enters Exantha. Although there were different sections, Javanese people find it difficult to distinguish between $C$. soloensis, C. longa, and C. zanthorrhiza.

Based on Table 2, the vernacular names of $C$. soloensis covering temu glenyeh, temu blenyeh, and kunir kuning (yellow turmeric). Valeton and Heyne called temu glenyeh with the old spelling of gelenje and belenje (Valeton 1918). The people of Bantul, Yogyakarta, Gunungkidul, Semarang, Magelang, Trenggalek call this plant as temu blenyeh. Residents of Karanganyar, Pacitan, and Wonogiri gave the name of a plant similar to turmeric with temu glenyeh. However, residents of Sawoo Sub-district (Ponorogo District), C. soloensis have another name as kunir kuning (yellow turmeric) because the plants are similar to C. longa while the color of the rhizome is orange-yellowish. Scientific publications often use the vernacular name Тетu Glenyeh (Marliyana et al. 2018; Vitasari et al. 2016). Temu Glenyeh and Temu Blenyeh are two vernacular names that are often used by the Javanese community.

Though Curcuma can grow at high altitudes such as above 1000-2500 m above sea level (Sasikumar 2005), $C$. soloensis in Java is found at an altitude of $114 \mathrm{~m}$ asl. (Tegalrejo Village, Tegalrejo Sub-district, Yogyakarta City) until $826 \mathrm{~m}$ asl. (Tawangmangu Sub-district, Karanganyar District), average altitude of occurrence being $361 \mathrm{~m}$ asl. Along with varying altitudinal parameters, $C$. soloensis occurs in varied habitats.

These plants usually cluster to form clumps, which in turn are formed by pseudo-stems with 2-9 leaves. The leaves of $C$. soloensis are $30-100 \mathrm{~cm}$ long $\times 10-24 \mathrm{~cm}$ wide. The number of clumps ranges from 2-34 pseudostems per clump and the average number of pseudo-stems in a clump is 12 .

Curcuma soloensis generally grows in wild habitats such as under teak (Tectona grandis), bamboo (Dendrocalamus asper), lamtoro (Leucaena leucocephala), flamboyant (Delonix regia), mahogany (Swietenia macrophylla), and cassava (Manihot utilissima). As C. soloensis occurs naturally, it generally does not need extra care from local communities (Roemantyo 2000). Interestingly, in some areas of Karangmojo Sub-district (Gunungkidul District) and Ngadirojo Sub-district (Wonogiri District), the spurt of $C$. soloensis growth during the rainy season is considered as weed.

Species abundance refers to the number of individuals per species per site and relative abundance (mostly used as percentage) is one of the factors considered in biodiversity studies. Relative species abundance helps in finding out how common a sampled taxa is relative to the other sampled taxa at a site. In Java Island, the three sites with highest relative abundance index scores for the $C$. soloensis were Pajangan of Bantul District (19.80\%), Tirtomoyo of Wonogiri District (15.84), and Tawangmangu of Karanganyar District (11.22) (Table 3).

\section{Variation of Curcuma soloensis Valeton in Java}

The variation lies in habit, stem color, leaf shape, rhizome shape, rhizome flesh color, and tuber shape. The observations of the variation of $C$. soloensis are shown in Figure 2.

Curcuma soloensis is a herb that forms rhizome at the base. Curcuma is composed of a pseudo-stem which is derived from leaf fronds and has broad leaves (Sirirugsa et al. 2007). C. soloensis plants are mostly upright, though semi-erect type plants are also found in the Imogiri and Tirtomoyo areas.

Curcuma soloensis propagates vegetatively through rhizomes and its morphology consists of the primary rhizome (empu), secondary rhizome (entik), rhizome roots, and has a tuber. The main rhizomes in $C$. soloensis are generally round $(48 \%)$, conical $(32 \%)$, elongated $(12 \%)$, and ellipsoidal (8\%) (Figure 2). Ellipsoidal form can be found in the Nawangan Pacitan and Bendungan Trenggalek. The main rhizome has a large number of entic and clustered. The number of odd branches ranges from 2 to 7. C. soloensis generally have primary, secondary and tertiary rhizomes. The secondary rhizome is larger than the primary rhizome. Rhizome also has internode and node. The number of nodes on $C$. soloensis ranges from 5-13 pieces. Each node develops the first branch (secondary rhizome) and they in turn branch off again to form tertiary rhizomes. The main rhizome will experience weathering when the seasons change. The color of the rhizome is one of the important characters for distinguishing between three species of collected Curcuma (Backer and van den Brink 1968; Valeton 1918). The color of the C. soloensis rhizome in the outer region (cortex) has a brighter color than the color of the rhizome in the region (stele) (Sungkawati et al. 2019). Greyed-orange group 163-strong orange-yellow B rhizome flesh on the inside, while the outside is yelloworange group-14-vivid yellow A. There is the same color on the outside (cortex) and inside (stele), that is greyedorange group 163-strong orange-yellow B. Endodermic rings that limit the outer and inner layers are clearly visible or unclear. The pseudo-stem of C. soloensis is composed of leaf fronds. Pseudo-stems appear from rhizome nodes. Pseudo-stem functions to support the leaf blade. The number of pseudo-stems in one family is 2-34. The discovery of the most number of pseudostem clumps in Tawangmangu Sub-district. Incidentally in the area adjacent to the location of Tawangmawu Center for Traditional Medicinal Plants and Medicines as a research center for medicinal plants. Pseudo-stem color is dominated by yellow-green 144-strong yellow-green A. Color variations found yellow-green 144-strong yellowgreen a $(72 \%)$, yellow-green group 146-moderate yellowgreen b $(8 \%)$, green group143-strong yellow-green b (8\%), 151 -strong yellowish yellow a $(4 \%)$ yellow-green group, 144 -strong yellow-green $\mathrm{b}$ yellow group (4\%), and n144strong yellow b yellow group (4\%). 
Tabel 2. Accession of Curcuma soloensis found on the Java Island, Indonesia

\begin{tabular}{|c|c|c|c|c|c|c|c|}
\hline $\begin{array}{l}\text { No. } \\
\text { Acc. }\end{array}$ & Location & $\begin{array}{l}\text { Vernacular } \\
\text { name }\end{array}$ & $\begin{array}{l}\text { Height } \\
\text { (m asl) }\end{array}$ & Latitude & Longitude & $\begin{array}{l}\text { Abun } \\
\text { dance }\end{array}$ & Habitat information \\
\hline CS-01 & Imogiri Sub-district, Bantul District, Yogyakarta & Temu Blenyeh & 427 & $7^{\circ} 55^{\prime} 44$ "S & $110^{\circ} 25^{\prime} 58^{\prime \prime} \mathrm{E}$ & 2 & Shaded under the Jati tree \\
\hline CS-02 & Sidorejo Village, Tirtomoyo Sub-district, Wonogiri District, Central Java & Temu Glenyeh & 382 & $7^{\circ} 55^{\prime} 58^{\prime \prime} \mathrm{S}$ & $111^{\circ} 07^{\prime} 31^{\prime \prime} \mathrm{E}$ & 12 & Shaded under the Lamtoro tree \\
\hline C2-03 & Sidorejo 2 Village, Tirtomoyo Sub-district, Wonogiri District, Central Java & Temu Glenyeh & 393 & $7^{\circ} 55^{\prime} 58^{\prime \prime} \mathrm{S}$ & $111^{\circ} 07^{\prime} 30^{\prime \prime} \mathrm{E}$ & 5 & Shaded under a Bamboo \\
\hline CS-04 & Tawangmangu Sub-district Karanganyar District, Central Java & Temu Glenyeh & 826 & $7^{\circ} 38^{\prime} 32^{\prime \prime} \mathrm{S}$ & $111^{\circ} 06^{\prime} 15^{\prime \prime} \mathrm{E}$ & 34 & Shaded under the Flamboyan tree \\
\hline CS-05 & Tegalrejo Sub-district, Yogyakarta City, Yogyakarta & Temu Blenyeh & 114 & $7^{\circ} 47^{\prime 2} 22^{\prime \prime} \mathrm{S}$ & $110^{\circ} 21^{\prime} 01^{\prime \prime} \mathrm{E}$ & 2 & Open \\
\hline CS-06 & Karangmojo Sub-district, Gunungkidul District, Yogyakarta & Temu Blenyeh & 226 & $7^{\circ} 53^{\prime} 19^{\prime \prime} \mathrm{S}$ & $110^{\circ} 41^{\prime} 10^{\prime \prime} \mathrm{E}$ & 30 & Shaded under the Jati tree \\
\hline CS-07 & Patuk Sub-district, Gunungkidul District, Yogyakarta & Temu Blenyeh & 153 & $7^{\circ} 52^{\prime} 47^{\prime \prime} \mathrm{S}$ & $110^{\circ} 31^{\prime} 33^{\prime \prime} \mathrm{E}$ & 15 & Shaded under a Bamboo \\
\hline CS-08 & $\begin{array}{l}\text { Godegan RT } 003 \text { RW } 001 \text { Jembrak Village, Pabelan Sub-district, Semarang District, } \\
\text { Central Java }\end{array}$ & Temu Blenyeh & 575 & $7^{\circ} 1$ & $110^{\circ}$ & 24 & Shaded under Bamboo and Jati trees \\
\hline CS-09 & Pakis Sub-district, Magelang District, Central Java & Temu Blenyeh & 706 & $7^{\circ} 27^{\prime} 30^{\prime \prime} \mathrm{S}$ & $110^{\circ} 19^{\prime} 05^{\prime \prime} \mathrm{E}$ & 12 & Shaded under the Papaya \\
\hline CS-10 & Mangunan Village, Dlingo Sub-district, Bantul District, Yogyakarta & Temu Blenyeh & 365 & $7^{\circ} 55^{\prime} 42^{\prime \prime} \mathrm{S}$ & $110^{\circ} 25^{\prime} 19^{\prime \prime} \mathrm{E}$ & 2 & Shaded under a Bamboo \\
\hline CS-11 & Gedong Village, Ngadirojo Sub-district, Wonogiri District, Central Java & Temu Glenyeh & 195 & $7^{\circ} 51^{\prime 2} 26^{\prime \prime} \mathrm{S}$ & $110^{\circ} 59^{\prime} 00^{\prime \prime} \mathrm{E}$ & 26 & Shaded under the Flower Shoe tree \\
\hline CS-12 & Ngarjosari Village, Tirtomoyo Sub-district, Wonogiri District, Central Java & Temu Glenyeh & 168 & $7^{\circ} 56^{\prime} 45^{\prime \prime} \mathrm{S}$ & $111^{\circ} 02^{\prime} 21^{\prime \prime} \mathrm{E}$ & 31 & Shaded under the Jati tree \\
\hline CS-13 & Penggung Village, Nawangan Sub-district, Pacitan District, East Java & Temu Glenyeh & 809 & $7^{\circ} 58^{\prime} 13^{\prime \prime} \mathrm{S}$ & $111^{\circ} 07^{\prime} 48^{\prime \prime} \mathrm{E}$ & 7 & Shaded among bushes \\
\hline CS-14 & Penggung Village, Nawangan Sub-district, Pacitan District, East Java & Temu Glenyeh & 815 & $7^{\circ} 58^{\prime} 13^{\prime \prime} \mathrm{S}$ & $111^{\circ} 07^{\prime} 48^{\prime \prime} \mathrm{E}$ & 6 & Shaded among bushes \\
\hline CS-15 & Penggung Village, Nawangan Sub-district, Pacitan District, East Java & Temu Glenyeh & 816 & $7^{\circ} 58^{\prime} 13^{\prime \prime} \mathrm{S}$ & $111^{\circ} 07^{\prime} 48^{\prime \prime} \mathrm{E}$ & 6 & Shaded under the Banana \\
\hline CS-16 & Sawoo Sub-district, Ponorogo District, East Java & Kunir Kuning & 239 & $7^{\circ} 59^{\prime} 35^{\prime \prime} \mathrm{S}$ & $111^{\circ} 34^{\prime} 39^{\prime \prime} \mathrm{E}$ & 3 & Shaded under the Banana \\
\hline CS-17 & Sumur Village, Bendungan Sub-district, Trenggalek District, East Java & Temu Blenyeh & 319 & $8^{\circ} 00^{\prime} 17^{\prime \prime} \mathrm{S}$ & $111^{\circ} 41^{\prime} 54^{\prime \prime} \mathrm{E}$ & 12 & Shaded under the Cassava \\
\hline CS-18 & Joho, Pucanganak Village, Tugu Sub-district, Trenggalek District, East Java & Temu Blenyeh & 151 & $8^{\circ} 01^{\prime \prime} 38^{\prime \prime} \mathrm{S}$ & $111^{\circ} 36^{\prime} 30^{\prime \prime} \mathrm{E}$ & 2 & Shaded under the Flamboyan tree \\
\hline CS-19 & Kucur-Kucur, Nglinggis Village, Tugu Sub-district, Trenggalek District, East Java & Temu Blenyeh & 221 & $8^{\circ} 02^{\prime} 35^{\prime \prime} \mathrm{S}$ & $111^{\circ} 35^{\prime} 50^{\prime \prime} \mathrm{E}$ & 6 & Shaded under the Jati tree \\
\hline CS-20 & Blumbang Village, Sawoo Sub-district, Ponorogo District, East Java & Temu Blenyeh & 394 & $8^{\circ} 01^{\prime} 44^{\prime \prime} \mathrm{S}$ & $111^{\circ} 34^{\prime} 33^{\prime \prime} \mathrm{E}$ & 6 & Shaded among bushes \\
\hline CS-21 & Krebet RT 05, Sendangsari Village, Pajangan Sub-district, Bantul District, Yogyakarta & Temu Blenyeh & 147 & $7^{\circ} 51^{\prime} 19^{\prime \prime} \mathrm{S}$ & $110^{\circ} 17^{\prime} 51^{\prime \prime} \mathrm{E}$ & 6 & Shaded under the Jati tree \\
\hline CS- 22 & Krebet RT 05, Sendangsari Village, Pajangan Sub-district, Bantul District, Yogyakarta & Tembu Blenyeh & 147 & $7^{\circ} 51^{\prime} 17^{\prime \prime} \mathrm{S}$ & $110^{\circ} 17^{\prime} 51^{\prime \prime} \mathrm{E}$ & 12 & Shaded under the Jati tree \\
\hline CS-23 & Krebet RT 05, Sendangsari Village, Pajangan Sub-district, Bantul District, Yogyakarta & Temu Blenyeh & 148 & $7^{\circ} 51^{\prime} 18^{\prime \prime} \mathrm{S}$ & $110^{\circ} 17^{\prime} 51^{\prime \prime} \mathrm{E}$ & 14 & Shaded under the Jati tree \\
\hline CS-24 & Krebet RT 05, Sendangsari Village, Pajangan Sub-district, Bantul District, Yogyakarta & Temu Blenyeh & 145 & $7^{\circ} 51^{\prime} 19^{\prime \prime} \mathrm{S}$ & $110^{\circ} 17^{\prime} 51^{\prime \prime} \mathrm{E}$ & 14 & Shaded under the Jati tree \\
\hline CS- 25 & Krebet RT 05, Sendangsari Village, Pajangan Sub-district, Bantul District, Yogyakarta & Temu Blenyeh & 145 & $7^{\circ} 51^{\prime \prime 2} 20^{\prime \prime} \mathrm{S}$ & $110^{\circ} 17^{\prime} 51^{\prime \prime} \mathrm{E}$ & 14 & Shaded under the Jati tree \\
\hline CL-01 & Demakan Lama RT 25 RW 7, Tegalrejo Sub-district, Yogyakarta City, Yogyakarta & Kunir & 114 & $7^{\circ} 47^{\prime} 23^{\prime \prime} \mathrm{S}$ & $110^{\circ} 21^{\prime} 02^{\prime \prime} \mathrm{E}$ & 34 & Open \\
\hline CX-01 & RT 21 RW 6 Tegalrejo, Tegalrejo Sub-district, Yogyakarta City, Yogyakarta & Temulawak & 115 & $7^{\circ} 47^{\prime} 20^{\prime \prime} \mathrm{S}$ & $110^{\circ} 21^{\prime} 09^{\prime \prime} \mathrm{E}$ & 20 & Open \\
\hline CX-02 & Patuk Sub-district, Gunungkidul District, Yogyakarta & Temulawak & 148 & $7^{\circ} 52^{\prime} 45^{\prime \prime} \mathrm{S}$ & $110^{\circ} 31^{\prime} 35^{\prime \prime} \mathrm{E}$ & 20 & Shaded under the mahogany tree \\
\hline CL-02 & RT 7 RW 3 Salebu Village, Majenang Sub-district, Cilacap District, Central Java & Kunyit & 410 & $7^{\circ} 16^{\prime} 26^{\prime \prime} \mathrm{S}$ & $108^{\circ} 43^{\prime} 15^{\prime \prime} \mathrm{E}$ & 5 & Under the coconut tree \\
\hline CL-03 & Sukamanah Village, Sindangkasih Sub-district, Ciamis District, West Java & Kunyit & 517 & $7^{\circ} 15^{\prime} 57^{\prime \prime}$ & $108^{\circ} 13^{\prime} 04^{\prime \prime} \mathrm{E}$ & 4 & Open \\
\hline CL-04 & RT 3 RW 4 Indihiang Village, Indihiang Sub-district, Ciamis District, West Java & Kunyit & 407 & $7^{\circ} 17^{\prime} 37^{\prime \prime}$ & $108^{\circ} 11^{\prime} 51^{\prime \prime} \mathrm{E}$ & 3 & Shaded under the Banana \\
\hline CX-03 & Bendungan Sub-district, Trenggalek District, East Java & Temulawak & 529 & $7^{\circ} 57^{\prime} 33^{\prime \prime} \mathrm{S}$ & $111^{\circ} 42^{\prime} 06^{\prime \prime} \mathrm{E}$ & 10 & Shaded under the Jati tree \\
\hline
\end{tabular}




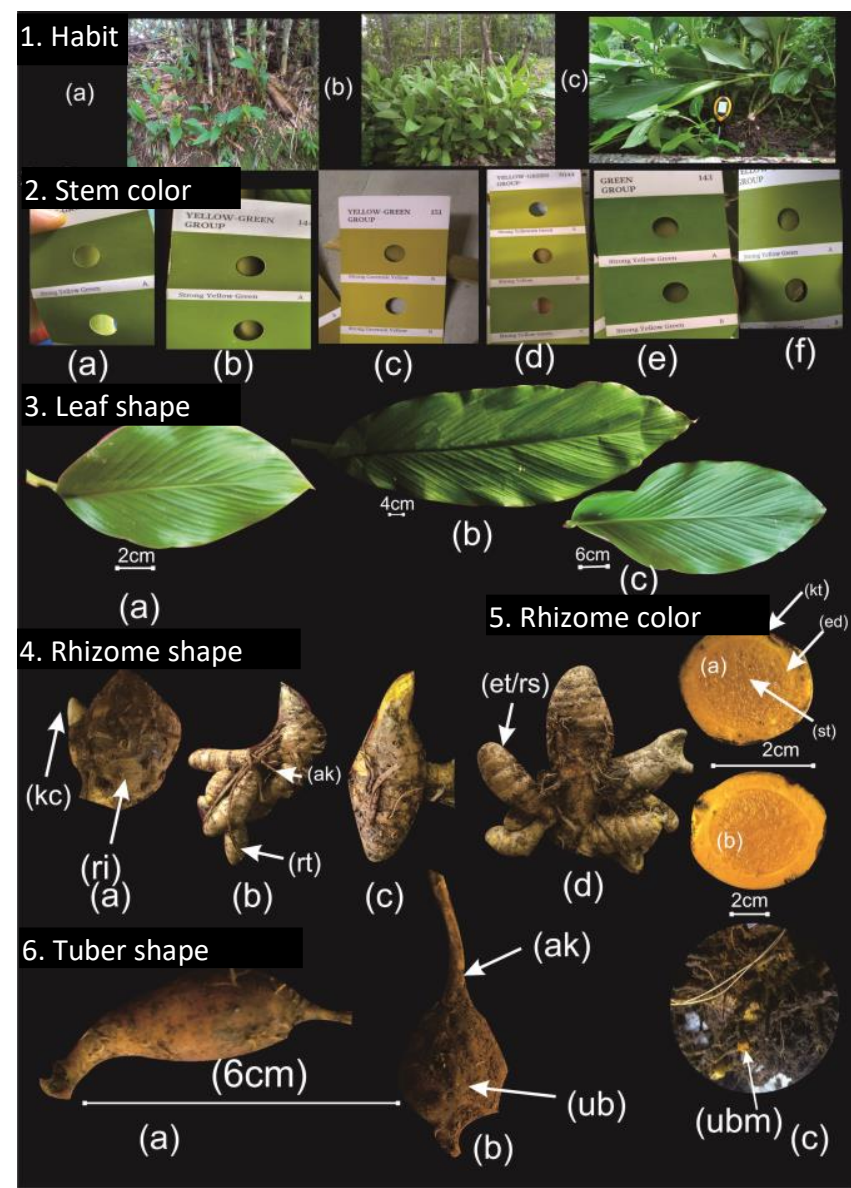

Figure 2. Variation of Curcuma soloensis: 1. habit: (a) semi erect under the bamboo tree, (b) erect under the jati tree, erect open; 2. stem color: (a) yellow green 144-strong yellow green a (b) yellow green group 146-moderate yellow green $b(c)$ yellow green group 151-strong greenish yellow a (d) yellow green group n144-strong yellow b (e) green group 143-strong yellow green b (f) yellow green group 144-strong yellow green $b$; 3.leaf shape: (a) ovoid (ovatus); (b) lancet (c) elongated (oblong); 4. rhizome shape: (a) rounded; (b) cone; (c) ellipse; (d) extends; information: (kc) buds, (ri) primary rhizomes, et/rs/secondary rhizomes, (rt) tertiary rhizomes, (ak) roots, and (ru) segments of rhizomes; 5. rhizome color of flesh: 143 green strong group green yellow a, yellow green group 144 strong yellow green b, 137-moderate olive green group green, 137-moderate olive green group green, yellow 144strong yellow green group a, green group 138-moderate yellowish green a, and green group 143-strong yellow green b (a) unclear endodermic ring (b) clear endodermic ring; (c) endodermic ring is not clear, information: (kt) cortex, (ed) endodermis, (st) stele; 6 . tuber shape: (a) long fusiform; (b) fusiform; (c) fused tubers; description: (ak) roots; (ub) tubers; and (ubm) tubers melt

Leaf characters observed were leaf stalk texture, leaf blade color, leaf blade shape, leaf tip, leaf blade width, number of leaf strands, leaf edges, leaf veins, the presence of dorsal and ventral leaf signs, mid-rib color, mid-rib tinge of leaves. Leaf stalk texture is measured from the ground to the base of the leaf. The texture of $C$. soloensis petiole is generally rough. Some are found refined in the Karangmojo and Tirtomoyo areas. Leaf-blade color is dominated by Green group 143-strong yellow-green A. The
Tabel 3. Abundance of Curcuma soloensis in Java Island, Indonesia

\begin{tabular}{lcc}
\hline \multicolumn{1}{c}{ Sub-district } & Abundance & $\begin{array}{c}\text { Relative abundance } \\
\text { percentage }\end{array}$ \\
\hline Imogiri & 2 & $0.66 \%$ \\
Tirtomoyo & 48 & $15.84 \%$ \\
Tawangmangu & 34 & $11.22 \%$ \\
Tegalrejo & 2 & $0.66 \%$ \\
Karangmojo & 30 & $9.90 \%$ \\
Patuk & 15 & $4.95 \%$ \\
Pabelan & 24 & $7.92 \%$ \\
Pakis & 12 & $3.96 \%$ \\
Dlingo & 2 & $0.66 \%$ \\
Ngadirojo & 26 & $8.58 \%$ \\
Nawangan & 19 & $6.27 \%$ \\
Sawoo & 9 & $2.97 \%$ \\
Bendungan & 12 & $3.96 \%$ \\
Tugu & 8 & $2.64 \%$ \\
Pajangan & 60 & $19.80 \%$ \\
Total & 303 & $100 \%$ \\
\hline
\end{tabular}

color of the leaves of $C$. soloensis varies greatly from green group 143-strong yellow-green a (44\%), green group 137moderate olive green a (28\%), yellow-green group 144 strong yellow-green $\mathrm{b}(8 \%)$, yellow-green group 144strong yellow-green a $(8 \%)$, green group 137-moderate olive green b (4\%), green group 138-moderate yellowishgreen a (4\%), and 143-strong yellow-green b (4\%) green group. Leaf shape is lancet (68\%), elongated (28\%), and ovoid $(4 \%)$. Oblong and lancet strands are also found in Thailand (Chaveerach et al. 2007).

Tubers on C. soloensis are at the tip of the root. The roots are linear with two outer and inner layers (Uma and Muthukumar 2014). Root length ranges between 7-34 cm. Exploration results showed that not all main rhizomes were found. Areas found by masters are in the areas of Tirtomoyo, Karangmojo, Pabelan, Pakis, and Display. There are two types of tubers in $C$. soloensis, namely fusiform and long fusiform. This is in accordance with what was conveyed by Sasikumar (2005), that the variations of masters found in the Himalayas are fusiform and long fusion form. Most of the exploration points were not found at the tip of the root tuber. This is because sometimes the tubers come to fuse into the soil during the rainy season. Researchers get evidence that the tubers also fuse into the ground, when conducting exploration activities in the Krebet Pajangan Bantul area. The shape of the tuber has become a yellowish-orange powder attached to the clay. Images of $C$. soloensis tuber variations can be seen in Figure 2.

Curcuma soloensis flowers were found in Karangmojo Sub-district, Gunungkidul District, Yogyakarta in January. C. soloensis flowers take place from November to May, while C. zanthorrhiza flower in April and May (Škorničková and Sabu 2005). Of the 25 samples obtained, only in Karangmojo and Tirtomoyo were found in flowering conditions. Even the Krebet and Pabelan people said that $C$. soloensis had no flower because it was based on observations during seeing $C$. soloensis's growth. $C$. 
soloensis flowers can be used as ornamental plants in China (Zhang et al. 2011). The arrangement of C. soloensis flowers is shown in Figure 3. The striking difference between the flowers of $C$. soloensis, $C$. longa and $C$. zanthorrhiza is in the colors of coma and Bractea. $C$. soloensis is pink, whereas in C. zanthorrhiza is dark red (Škorničková and Sabu 2005) and C. longa is whitishgreen or dark yellow (Sirirugsa 1998). In previous studies also reported that the coma in C. soloensis Valeton is white to greenish (Rahman and Yusuf 2012). The equation lies in the shape of the longa type anthera and at the base of the ovary, there are hairs (Chaveerach et al. 2008; Rahman and Yusuf 2012; Sirirugsa et al. 2007).

\section{Description of Curcuma soloensis Valeton in Java Island}

Morphological characterization and identification were based on $C$. soloensis relationship analysis based on preexisting identification (Backer and van den Brink 1968; Delin and Larsen 2000; Sasikumar 2005; Sungkawati et al. 2019). Based on the characterization and identification it is known that there are two major groups, namely the first group is the collective species $C$. viridiflora Roxb. (Temu Glenyeh and $C$. longa) and $C$. zedoaria (Berg.) Roscoe represented by $C$. zanthorrhiza. Backer and van den Brink (1968), divided Curcuma into three collective species, namely $C$. aurantiaca Roxb., $C$. viridiflora Roxb., and $C$. zedoaria (Berg.) Roscoe. Characterization includes habit, stems, leaves, flowers, rhizomes, tubers, and roots. The following are the morphological characteristics of $C$. soloensis as follows:

\section{Curcuma soloensis Valeton (temu glenyeh)}

Habit Perennial herb, erect to semi-erect, $73-220 \mathrm{~cm}$ in height, pseudo-stem yellow-green 144-strong yellow-green A. Stem composed of leaf mid-ribs, number of pseudostems 2-34 in one clump, leaf stalk texture mostly rough, leaf blade color dominated by green group 143-strong yellow-green A. Leaves lanceolate, longitudinal (oblong), and ovoid on the first leaf, leaf tip tapered (acuminate), acute, leaf base attenuate to acute, length of leaf mid-rib (vaginal) between $36-125 \mathrm{~cm}$, leaf blade $30-100 \mathrm{~cm}$ long, 10-24 cm wide, 2-9 leaf blades in one pseudo-stem, leaf margin medium $(76 \%)$, high $(16 \%)$ and low $(8 \%)$, tight leaf veins $(68 \%)$ and tenuous $(32 \%)$, dorsal and ventral surface smooth, leaf blade (mid-rib) green, tinge at dorsal and ventral mid-rib absent. The earliest growths that appear on the surface of the soil are vegetative organs (leaf buds). The rhizome below the surface of the soil, round, elongated, elliptical to conical in shape, the aroma of the rhizome nil to rusty, taste bitter, second side rhizome present, endodermic ring of the primary rhizome clearly visible, the color of the rhizome at outermost (WDRBL) part is greyedorange group 163-strong orange-yellow B and yelloworange group-14-vivid yellow $\mathrm{A}$, the color of the inner rhizome (WDRBD) most are Greyed-Orange Group 163strong orange-yellow B and greyed-Orange Group N167Brownish Orange A, the outer skin color of the rhizome is mostly brown, the number of branches of the rhizome is 27 secondary rhizomes (entik), the number of rhizomes is 513 pieces, the diameter of the rhizomes is $3-6 \mathrm{~cm}$, the circumference of the rhizome $10-18 \mathrm{~cm}$, length of the secondary rhizome $3-12 \mathrm{~cm}$, the endodermic ring present, the diameter of the entik 1-4 inches, the perimeter of entik (secondary rhizome) is $6-10 \mathrm{~cm}$. Tubers present, sometimes absent, fusiform to longifusiform in shape, $2-8 \mathrm{~cm}$ long, located at the tip of the root. The roots are oblong and cylindrical in shape, yellow, brown, black, and whitish in color, root of 7-34 cm length, and mostly stolons are absent. Inflorescence position terminal (emerging from the tip of the pseudo-stem), height of the flower stalk (pedunculus) 10-13 cm, coma present, 9-10 steril bractea, coma 2-6 cm long, $0.5-1.5 \mathrm{~cm}$ broad, pink in color, lanceolate in shape, coma tip acute to acuminate, sepal white with blunt tip, petal yellow with blunt tip, labellum yellow, bractea ovoid, greenish, 4-6 cm long, 1.5-4.5 cm wide, tip blunt, number of fertile bractea 5-19 pieces, the type of anthera longa.

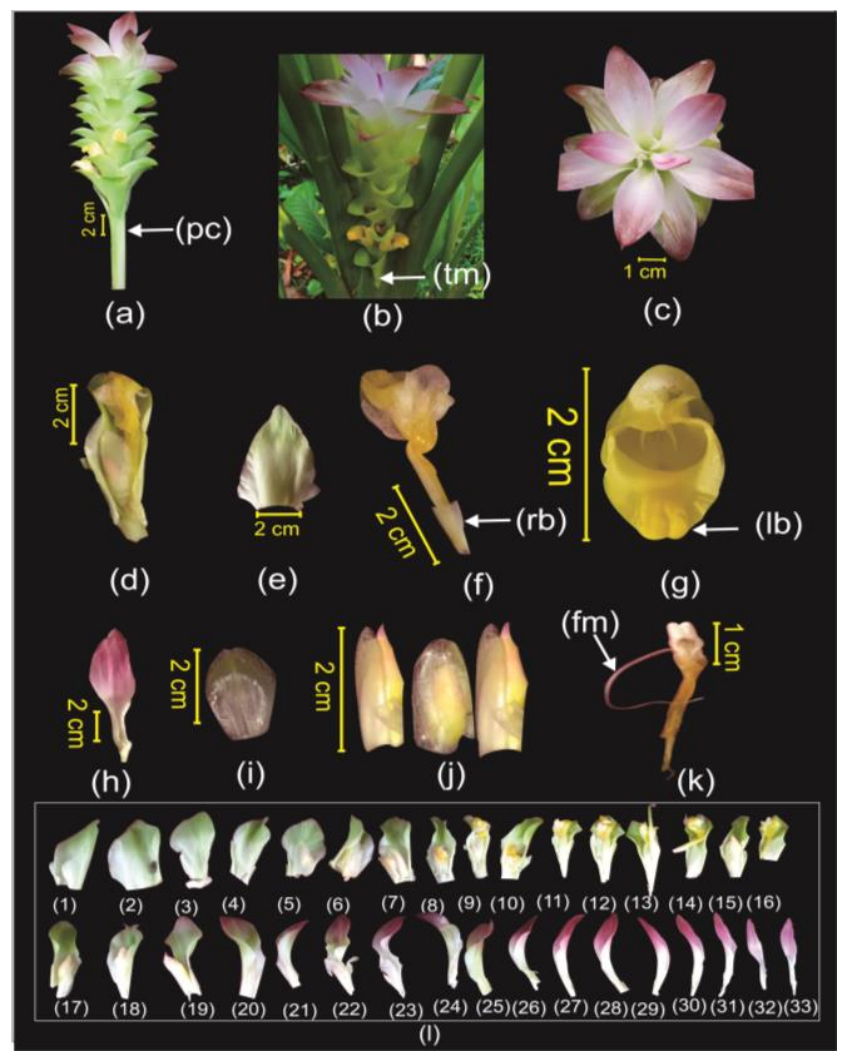

Figure 3. Arrangement of Curcuma soloensis flower: (a) Arrangement of compound flower in the form of bunches (b) flower coming out from the tip of pseudo-stem (c) visible on $C$. soloensis flower (d) bractea fertile (e) bractea sterile (f) pistil and C. soloensis fruit (ovary) (g) corolla in the form of a tube (h) coma (i) petal leaf (sepals) (j) petal (k) anthers (l) arrangement of bractea with number 33 from bottom to top, information: (pc ) pedunculus; (tm) type of terminal flowering; (fm) filament; (rb) hair fur. 


\section{Relationship of Curcuma soloensis Valeton in Java based on morphological character}

Relationship analysis of $C$. soloensis was conducted based on 45 characters consisting of 30 qualitative characters and 15 quantitative characters. The characters consist of 3 habit characters, 2 pseudo-stem characters, 16 leaf characters, 2 flower characters, 18 rhizome characters, 3 root characters, and 1 tuber character. Phenetic analysis used to look at the relationship between morphological characters of the $C$. soloensis in Java, there are two (2) types, namely cluster analysis and principal component analysis (PCA).

Based on the dendrogram (Figure 4) it can be seen that 32 OTUs have the same character so that they are integrated into the Similarity Index (IS) 0.617. These characters are found on the dorsal and ventral surfaces of the leaves. The upper or dorsal surface of $C$. soloensis, $C$. zanthorrhiza, and $C$. longa has a smooth (glabrous) surface. The repetition of $C$. soloensis, C. zanthorrhiza, and C. longa has a pinnate reinforcement. Maknoi (2006) and Sungkawati et al. (2019), states that most of the genus Curcuma has a leaf surface texture that is glabrous and some species have a hairy texture on the lower surface.

The dendrogram above has two large clusters namely cluster A which converges at IS 0.757 and cluster B that integrates at IS 0.665 . Cluster A consists of Curcuma zanthorrhiza, while Cluster B consists of $C$. longa and $C$. soloensis One may tentatively decide 85 percent similarity as the threshold for the species, 65 for genera and 45 for families (Singh, 2010). Based on similarity (0.665) $C$. soloensis and $C$. longa should be in different species, but this needs to be confirmed through other approaches, for example molecular. Valeton and Backer also separated them into separate species. Other studies report that the $C$. viridiflora group (C. soloensis Valeton and $C$. longa L.) separated from the $C$. zedoaria group with taxonomic evidence of anatomy and micromorphology (anther) (Sirirugsa et al 2007; Uma and Muthukamar 2014). This grouping is based on the character equation in the mid-rib color, mid-rib tinge, early growth, and the position of the inflorescence (Figure 5).

Early growth in $C$. soloensis and $C$. longa are generally first vegetative organs, whereas in $C$. zanthorrhiza flowers will appear (generative organs) first and are relatively short (Škorničková and Sabu 2005). According to one of the residents of Sidorejo Village, Tirtomoyo Sub-district, $C$. soloensis, and C. longa will grow leaf buds and their midribs, while in $C$. zanthorrhiza the flowers will usually appear first. Recognition differs precisely from residents of Pabelan Sub-district, Semarang and Bantul Pajangan, $C$. soloensis never appears flowers, only grow rhizome, pseudostems, and leaves.

Flowers on $C$. zanthorrhiza appear on the lateral side (arises from the node of the rhizome) then emerge out onto the ground (Škorničková and Sabu 2005; Valeton 1918). $C$. soloensis entered the collective species $C$. viridiflora Roxb. with terminal inflorescence type (Sirirugsa et al. 2007). $C$. soloensis and $C$. longa appear from the terminal side or the tip of the pseudo-stem (Delin and Larsen 2000; Valeton 1918). Pictures of inflorescence patterns in C. soloensis, $C$. longa, and $C$. zanthorrhiza can be seen in Figure 5. Valeton (1918), put $C$. soloensis and C. longa into the Mesantha section because inflorescent out from the center of the leaf stem, while $C$. zanthorrhiza entered the Exantha section because the inflorescent came out from the lateral side of the rhizome.

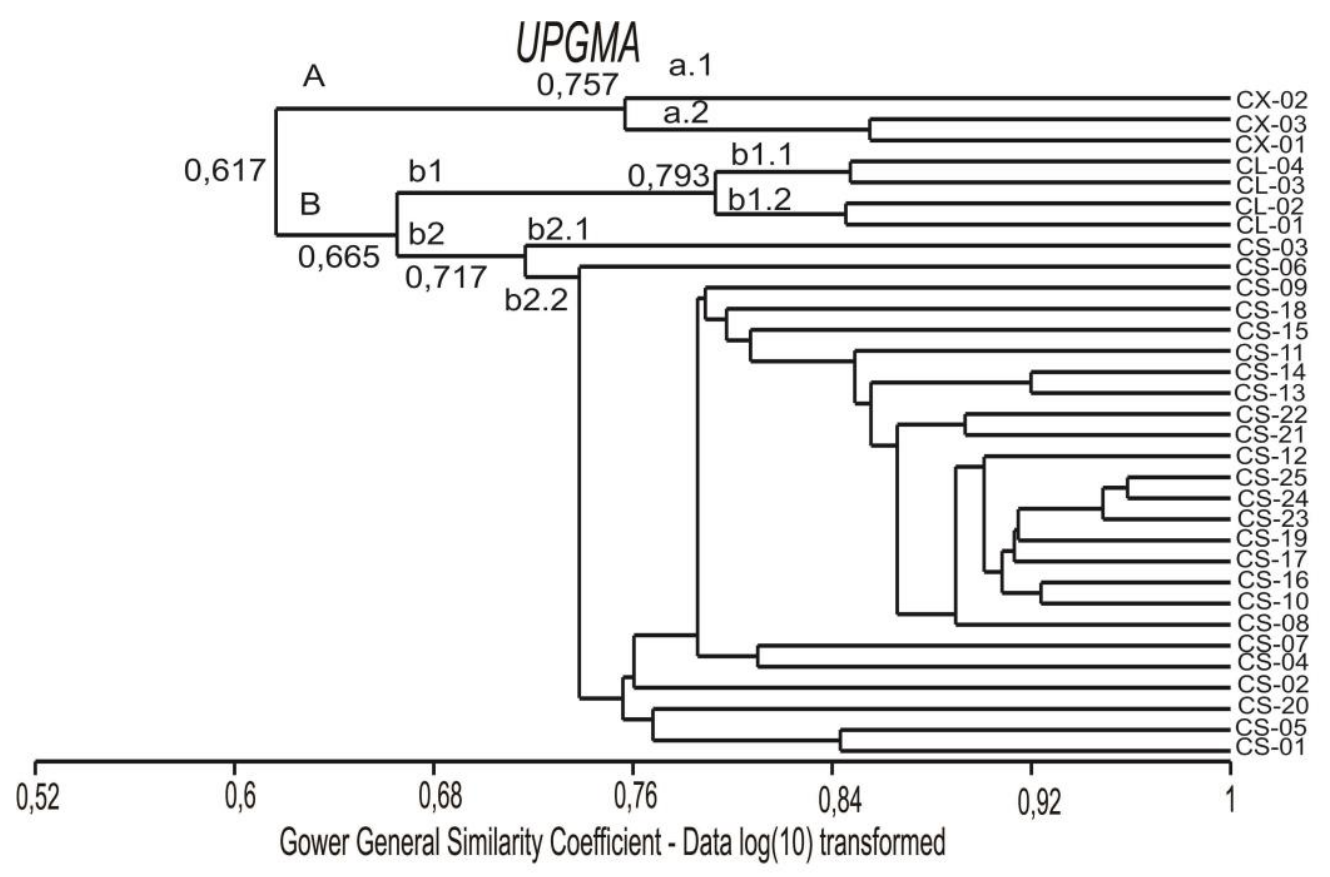

Figure 4. Dendrogram of Curcuma soloensis in Java, Indonesia based on morphological characters. Note: Accession code refers to Table 2. 

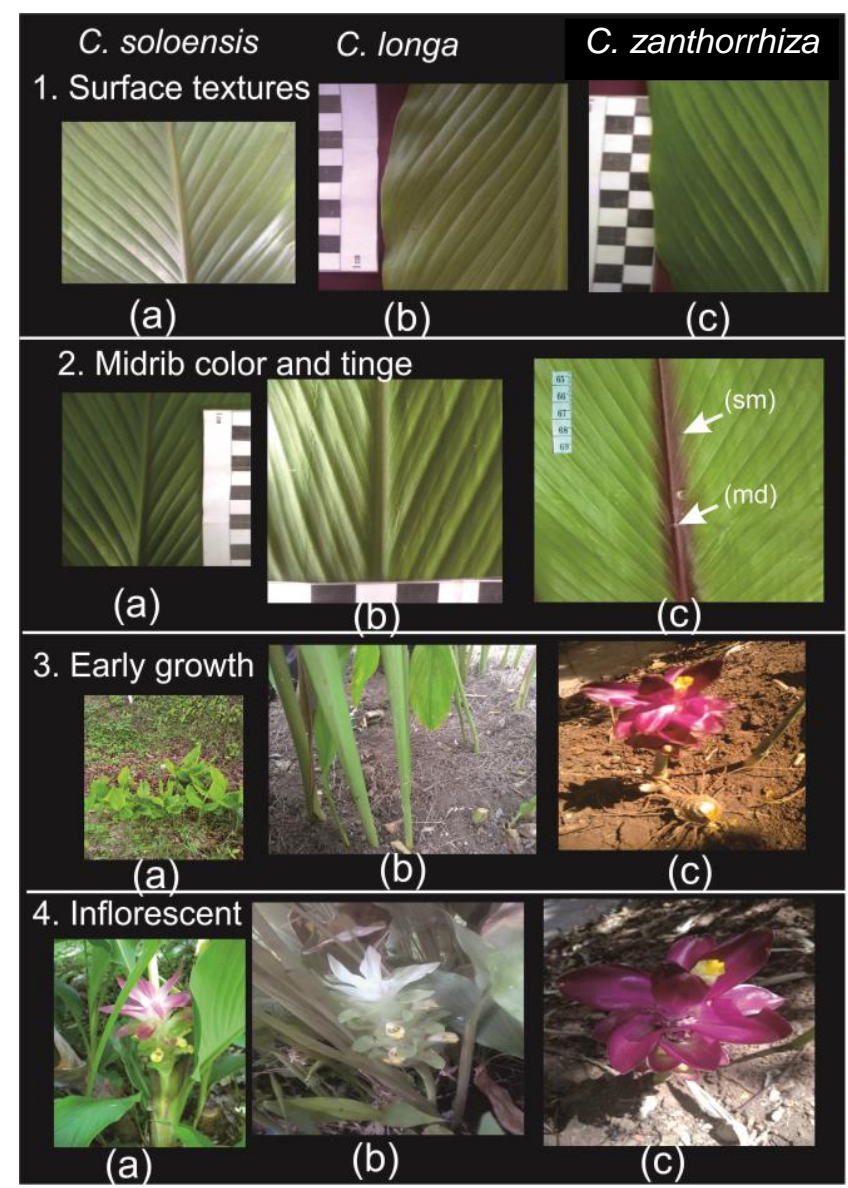

Figure 5. The basis of clustering: 1. Surface textures: (a) reinforcement of pinnate leaves, (b) dorsal: glabrous, (c) ventral: glabrous; 2. Mid-rib color and tinge: (a) Curcuma soloensis: green and no purple tinge (b) $C$. longa: green and no purple tinge (c) $C$. zanthorrhiza: purple and purple tinge, description: (MD) mid-rib, (sm) mid-rib tinge; 3 . Early growth: (a) C. soloensis: leaves and stems appear, (b) C. longa: leaves and stems appear (c) $C$. zanthorrhiza: flowers appear; 4. Inflorescence: (a) C. soloensis: arises from the tip of the pseudo-stem (terminal), (b) C. longa: arises from the tip of the pseudo-stem (terminal) (c) $C$. zanthorrhiza: arises from the node of the rhizome (lateral).

Cluster A has two small clusters, cluster a1 and a2. Cluster A is integrated into the IS value of 0.757. Cluster a1 consists of one accession CX-02 (C. zanthorrhiza, Patuk Sub-district). A2 cluster consists of two accessions CX 0-3 (C. zanthorrhiza Bandungan) and accession CX-01 ( $C$. zanthorrhiza Tegalrejo). The grouping of these two clusters is based on the length of the leaf mid-rib, leaf blade width, leaf edge, rhizome shape, rhizome circumference, and diameter of the leaf.

Cluster B is divided into two small groups namely b1 and b2. Cluster B merges at IS value 0.665. Cluster B consists of 29 OTUs. Groups are further divided into b1 and b2. group b1 belongs to the species $C$. longa and group b2 has $C$. soloensis Valeton. This grouping is based on the character similarity of rhizome taste. The taste of $C$. soloensis and $C$. longa were both bitter. Cluster b1 consists

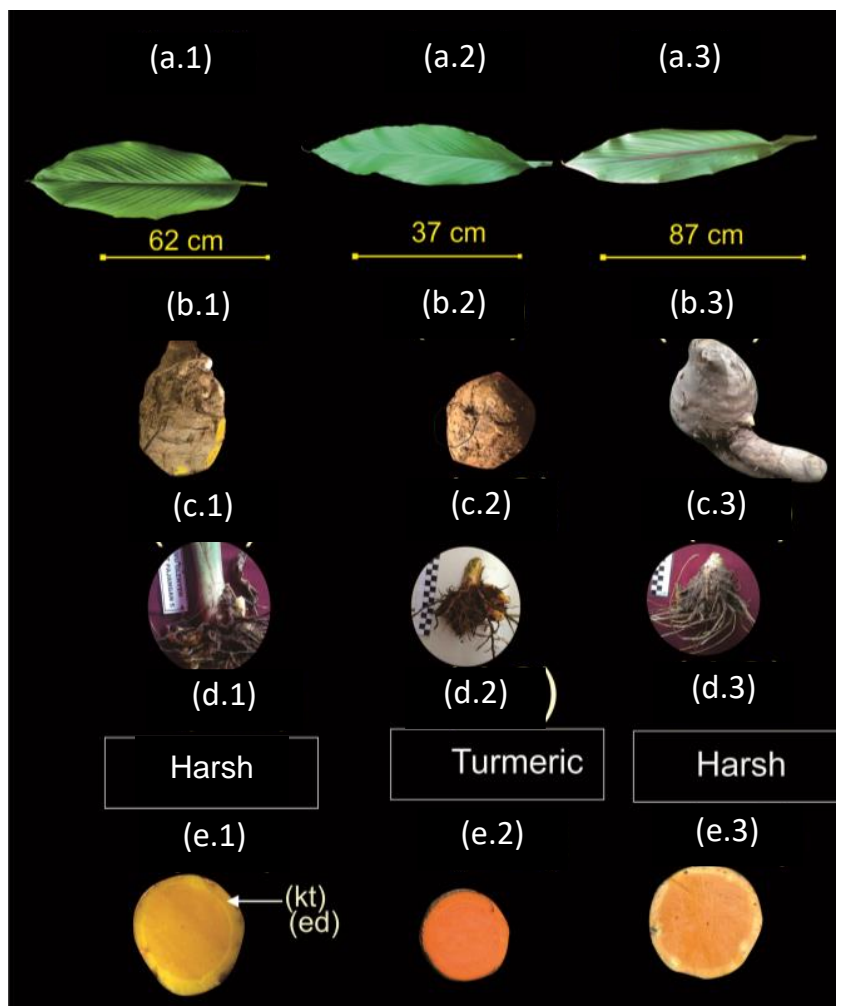

Figure 7. Characters that influence the grouping of Curcuma soloensis in Java Island (a) leaves color (WHD), (a1) C. soloensis: green group 143-strong yellow green A, (a2) C. longa: green group 137-moderate olive green B, (a3) C. zanthorrhiza: yellow green group 144-strong yellow green A; (b) leaves length (PHD), (b1) C. soloensis an average of $62 \mathrm{~cm}$, (b2) C. longa an average of $37 \mathrm{~cm}$ (b3) C. zanthorrhiza an average of $87 \mathrm{~cm}$; (c) rhizome shape, (c1) C. soloensis: ovoid, (c2) C. longa: round shape, (c3) C. zanthorrhiza: round shape; (d) root color (WA), (d1) $C$. soloensis: brown (d2) C. longa: yellow, (d3) C. zanthorrhiza: yellow; (e) aroma of rhizome (BR), (e1) C. soloensis: harsh; (e2) C. longa: turmeric, (e3) C. zanthorrhiza: harsh, (f) color of the outer rhizome (WDRBL) and inside (WDRBD), (f1) C. soloensis: outer and inner were greyed-orange group 163-strong orange yellow B, (f2) C. longa: outer and inner were orange group N25strong orange B, (f3) C. zanthorrhiza outer: yellow group 12vivid yellow A, inner: orange group N25-stronge orange A.

of two small clusters b1.1 and b1.2. The two groups merge at IS 0.793. (CL-03). Group b1.1 consists of two OTUs, namely Tasikmalaya (CL-04) and Ciamis (CL-03). Cluster b1.2 consists of two small clusters namely $C$. longa Ciamis (CL-03) and Majenang (CL-02), and Tegalrejo (CL-01).

The b2 group is further divided into two small clusters namely, b2.1 and b2.2. Cluster b2 merges at IS value 0.717 . Cluster b2.1 consists of one accession of the $C$. soloensis Tirtomoyo (CS-03) accession, and group b2.2 consists of 24 accessions of the $C$. soloensis CS-6, CS-09, CS-18, CS15, CS-11, CS-14, CS-13, CS-22, CS-21, CS-12, CS-25, CS-24, CS-23, CS-19, CS-17, CS-16, CS-10, CS-08, CS 07, CS-04, CS-02, CS-20, CS-05, CS-01. The grouping is based on the similarity of the plant type properties of $C$. soloensis and leaf habit found in $C$. soloensis in general is erect, only that the accession of CS-03 is semi-erect. 


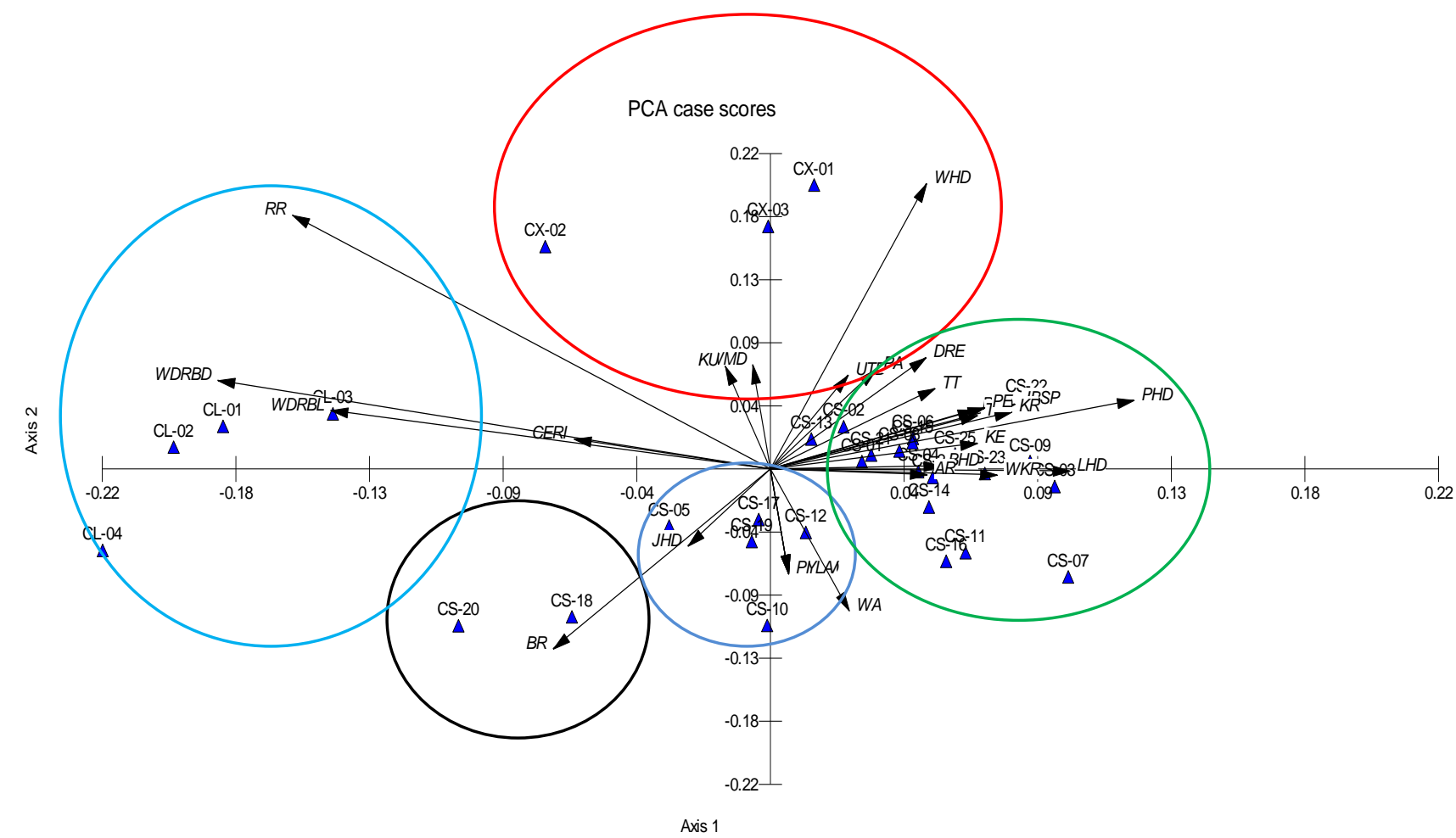

Vector scalina: 0.42

Figure 6. PCA of the Curcuma soloensis character's in Java Island, Indonesia

In general, morphological characters that play an important role in the grouping of $C$. soloensis in Java Island are the characters of leaves, roots, and rhizomes. Character that separates members of the C.viridiflora Roxb. species group. are leaf and rhizome characters (Backer and van den Brink 1968; Delin and Larsen 2000).

Principal component analysis (PCA) shows the pattern of grouping accessions (PCA arrows) and the role of each character in the grouping process (longer PCA arrows indicating greater role of character in grouping) (Figure 6). Usually, influential characters had an eigen value $\geq 2.00$ (Stevens and Tello 2014). The PCA results showed that the characters most involved in grouping were leaf blade color (WHD), leaf blade length (PHD), rhizome shape (BR), root color (WA), Rhizome flavor (RR), outer rhizome flesh color (WDRBL), and the color of the inner rhizome flesh (WDRBD) (Figure 7). This can be shown in the form of arrows of different lengths.

Based on the results of the PCA (Principal Component Analysis) (Figure 6) the characters that play an important role in grouping are shown by long arrow lines and each individual of the same type is marked with a circle. The accession of $C$. longa CL-01, CL-02, CL-03, and CL-04 is influenced by the color of the outer (WDRBL) and inner rhizomes (WDRBD) and the taste of the rhizome (RR). The color of $C$. longa in orange is influenced by the content of curcuminoids in rhizome meat ( $\mathrm{Li}$ et al. 2011). Accession of C. soloensis CS-18 and CS-20 is affected by aroma of rhizome (BR). Accessions of C. soloensis CS-05, CS-09, CS-10, CS-12, CS-17 are influenced by root color (WA).
18 accessions of $C$. soloensis CS-01, CS-02, CS-03, CS-04, CS-06, CS-07, CS-08, CS-11, CS-13, CS-14, CS-15, CS 16, CS-19, CS-21, CS-22, CS-23, CS-24, and CS-25 are affected by leaf length (PHD) length. Accession of $C$. zanthorrhiza Roxb. CX-01, CX-02, and CX-03 are influenced by the color of leaf blades (WHD). The purple color of the leaf mid-rib is influenced by anthocyanin levels (Sungkawati et al. 2019). During the dry season anthocyanin levels are higher because of the influence of sunlight and temperature.

The results of the study obtained 25 accessions of $C$. soloensis in East Java (Trenggalek, Pacitan, Ponorogo), Central Java (Wonogiri, Karanganyar, Magelang, and Semarang Sub-district), and DI Yogyakarta (Yogyakarta, Bantul, Gunungkidul). C. soloensis variation lies in habit, stem color, leaf shape, rhizome shape, rhizome flesh color, and tuber shape. The dendrogram divides 32 OTUs into two clusters on the phenon line 0.617 , namely, cluster A (C. zanthorrhiza) and cluster B (C. soloensis and C. longa). PCA results showed that the characters that had the most role in grouping were leaf blade color, leaf blade length, rhizome shape, root color, rhizome taste, outer and inner rhizome flesh color. This study needs to be continued at the molecular level with ISSR and ITS markers to confirm that C. soloensis is a separate species from C. longa. Although from the current morphological understanding, especially the similarity of flowering types it is possible that $C$. soloensis is a sub-species or variety of C. longa. 


\section{ACKNOWLEDGEMENTS}

This study was supported by the Plant Systematics Laboratory and the Genetics and Breeding Laboratory, Faculty of Biology, Universitas Gadjah Mada (UGM), Yogyakarta, Indonesia. Special thanks to the Research Directorate of UGM for funding through the final assignment recognition (RTA) program in 2020, number: 2607/UN1/DITLIT/DIT-LIT/PT/2020.

\section{REFERENCES}

Anuchapreeda S, Khumpirapang N, Rupitiwiriya K, Tho-Iam L, Saiai A Okonogi S, Usuki T. 2018. Cytotoxicity and inhibition of leukemic cell proliferation by sesquiterpenes from rhizomes of Mah-Lueang (Curcuma cf. viridiflora Roxb.). Bioorg Med Chem Lett 28 (3): 410414. DOI: 10.1016/j.bmcl.2017.12.029

Apavatjrut P, Anuntalabhochai S, Sirirugsa P, Alisi C. 1999. Molecular markers in the identification of some early flowering Curcuma L. (Zingiberaceae) species. Ann Bot 84 (4): 529-534. DOI: 10.1006/anbo.1999.0936

Backer CA, van den Brink RCB. 1968. Flora of Java (Spermatophytes only): Vol. III, Wolter-Noordhoff, Groningen.

Bos R, Windono T, Woerdenbag HJ, Boersma YL, Koulman A, Kayser O. 2007. HPLC-photodiode array detection analysis of curcuminoids in Curcuma species indigenous to Indonesia. Phytochem Anal 18 (2): 118-122. DOI: 10.1002/pca.959.

Chaveerach A, Sudmoon R, Tanee T, Sattayasai N, Sattayasai J. 2007. A new species of the genus Curcuma L., Zingiberaceae. Acta Phytotax Geobot 58 (2/3): 78-82. DOI: 10.18942/apg.KJ00004808380

Diastuti H, Asnani A, Chasani M. 2019. Antifungal activity of Curcuma xanthorrhiza and Curcuma soloensis extracts and fractions. IOP Con Ser Mater Sci Eng 509: 012047.

Delin W, Larsen K. 2000. Zingiberaceae. Flora of China 24: 322-377.

Hayakawa H, Minaniya Y, Ito K, Yamamoto Y, Fukuda T. 2011. Difference of curcumin content in Curcuma longa L. (Zingiberaceae) caused by hybridization with other Curcuma species. Am J Plant Sci 2: 111-119. DOI: 10.4236/ajps.2011.22013.

Heyne, K. 1987. Tumbuhan Berguna Indonesia. Yayasan Sarana Wana Jaya, Jakarta.

Kocaadam B, Şanlier N. 2017. Curcumin, an active component of turmeric (Curcuma longa), and its effects on health. Crit Rev Food Sci Nutr 57 (13): 2889-2895. DOI: 10.1080/10408398.2015.1077195

Kress WJ, Prince LM, Williams KJ. 2002. The phylogeny and a new classification of the gingers (Zingiberaceae): Evidence from molecular data. Am J Bot 89 (10): 1682-1696. DOI: 10.3732/ajb.89.10.1682.

Kew $\quad$ Science. $2020 . \quad$ Accessed at https://wcsp.science.kew.org/synonomy.do?name_id $=235249$, on 17.07.2020

Li S, Yuan W, Deng G, Wang P, Yang P, Aggarwal B. 2011. Chemical composition and product quality control of turmeric (Curcuma longa L.). Pharm Crop 2: 28-54. DOI: 10.2174/2210290601102010028.
Marliyana SD, Wartono MW, Wibowo FR, Munasah G. 2018. Isolasi dan identifikasi senyawa seskuiterpen dari Curcuma soloensis Val. (Temu Glenyeh). Jurnal Kimia Valensi 4 (2): 137-142 [Indonesian].

Mishra J, Bhardwaj A, Misra K. 2018. Curcuma sp.: The nature's souvenir for high-altitude illness. In: Misra K, Sharma P, Bhardwaj A (eds). Management of High Altitude Pathophysiology, Elsevier, Nederlands.

Rahman MA, Yusuf M. 2012. Three new species of Curcuma L. (Zingiberaceae) from Bangladesh. Bangladesh J Plant Taxon 19 (1): 79-84. DOI: 10.3329/bjpt.v19i1.10944

Roemantyo R. 2000. Analisis distribusi spasial marga Curcuma di Jawa (spatial distribution analyses of Curcuma in Jawa). Berita Biologi 5 (2): 203-215.

Sasikumar B. 2005. Genetic resources of Curcuma: Diversity, characterization and utilization. Plant Genet Resour 3 (2): 230-251. DOI: 10.1079/PGR200574

Silva ABWR, Herath H, Senanayake SP, Swarnathilaka DBR. 2018. Phenetic and genetic characterization of selected economically important species in the family Zingiberaceae. Sri Lankan J Biol 3 (1): 34-43. DOI: $10.4038 /$ sljb.v3i1.16

Singh, G. 2010. Plant Systematics (3rd ed.). Science Publishers, USA.

Sirirugsa P. 1998. Thai Zingiberaceae: Species Diversity and Their Uses. Proceedings of International Conference on Biodiversity and Bioresources-Conservation and Utilization, Phuket, Thailand, 23-27 November 1997.

Sirirugsa P, Larsen K, Maknoi C. 2007. The Genus Curcuma L. (Zingiberaceae): Distribution and classification with reference to species diversity in Thailand. Gard Bull Sing 59 (1 \& 2): 203-220.

Škorničková J, Sabu M. 2005. The identity and distribution of Curcuma zanthorrhiza Roxb. (Zingiberaceae). Gardens' Bull Singapore 57: 199-210.

Subositi D, Wahyono S. 2019. Study of the genus Curcuma in Indonesia used as traditional herbal medicines. Biodiversitas 20 (5): 1356-1361. DOI: 10.13057/biodiv/d200527

Sungkawati M, Hidayati L, Daryono BS, Purnomo. 2019. Phenetic analysis of Curcuma spp. in Yogyakarta, Indonesia based on morphological and anatomical characters. Biodiversitas 20 (8): 23402347. DOI: $10.13057 /$ biodiv/d200832

Stevens RD, Tello JS. 2014. On the measurement of dimensionality of biodiversity. Glob Ecol Biogeogr 23 (10): 1115-1125.

Theplantlist. 2020 Accessed http://www theplantis

Uma E Muthukumar T. 2014. Comparative root morphological anatomy of Zingiberaceae. Syst Biodivers 12 (2): 195-209. DOI: 10.1080/14772000.2014.894593

Valeton T. 1918. New Notes on the Zingiberaceae of Java and Malaya. Bulletin du Jardin Botanique Buitenzorg Ser 27 (2): 11.

Vitasari RA, Wibowo FR, Marliyana SD, Wartono MW. 2016. Isolation and identification of curcumin and bisacurone from rhizome extract of Temu Glenyeh (Curcuma soloensis Val). IOP Conf Ser Mat Sci Eng 107: 012063. DOI: 10.1088/1757-899X/107/1/012063.

Zhang S, Liu N, Sheng A, Ma G, Wu G. 2011. Direct and callus-mediated regeneration of Curcuma soloensis Valeton (Zingiberaceae) and ex vitro performance of regenerated plants. Scientia Horticulturae 130 (4): 899-905. DOI: 10.1016/j.scienta.2011.08.038. 